\title{
Evaluating Higher Education Institutions through Agency and Resources-Capabilities Theories. A Model for Measuring the Perceived Quality of Service
}

\author{
Avaliando instituições de Ensino Superior através de teorias de agência e \\ recursos de capacidades: um modelo para medir a qualidade visível do serviço \\ Evaluando instituciones de Educación Superior a través de teorías de agencia \\ y recursos de capacidades: un modelo para medir la calidad visible del servicio
}

JOSÉ GUADALUPE VARGAS-HERNÁNDEZ

\begin{abstract}
The objective of this paper is to explain through the agency theory and theory of resources and capacities as is the process of assessment in higher education institutions. The actors that are involved in the decision-making and the use that is giving the resources derived from repeatedly to practices that opportunistic diminishing the value that is given to the evaluation, in addition to the decrease in team work. A model is presented to measure the perception of service quality by students of the Technological Institute of Celaya, as part of the system of quality control, based on the theoretical support of several authors who have developed this topic (SERVQUAL and SERPERF) an instrument adapted to the student area of the institution called SERQUALITC is generated. The paper presents the areas or departments to assess and the convenient size, the number of items used by size and Likert scale, the validation study instrument is mentioned. Finally, it is presented the model that poses a global vision of quality measurement process including corrective action services that enable continuous improvement.
\end{abstract}

Keywords: Evaluation of Institutions of Higher education, Quality of service, Technological Institute of Celaya, university governance.

Resumo: O objetivo deste artigo é explicar, através da teoria da agência e da teoria de recursos e capacidades, como é o processo de avaliação em instituições de ensino superior. Os fatores que estão envolvidos nas tomadas de decisões e o uso atribuído aos recursos aparecem repetidamente como práticas oportunistas que diminuem o valor dado à avaliação, além da redução do trabalho em equipe. Um modelo é apresentado para medir a percepção da qualidade do serviço por alunos do Instituto Tecnológico de Celaya, como parte do sistema de controle de qualidade baseado no suporte teórico de vários autores que desenvolveram este tópico (SERVQUAL e SERPERF). Um instrumento adaptado para a área estudantil da instituição, chamado SERQUALITC, é gerado. O artigo apresenta as áreas ou departamentos para avaliar, bem como a dimensão conveniente, além do número de itens utilizados pela escala de Likert, e o instrumento de estudo para validação é mencionado. Finalmente, apresenta-se o modelo que aponta uma visão global do processo de avaliação de qualidade, incluindo serviços de ações corretivas que permitam a melhoria contínua. 
Palavras-chave: Avaliação das Instituições de Ensino Superior; qualidade de serviço; Instituto Tecnológico de Celaya; gestão universitária.

Resumen: El objetivo de este trabajo es explicar, a través de la teoría de la agencia y de la teoría de recursos y capacidades, cómo es el proceso de evaluación en las instituciones de educación superior. Los factores que se involucran en la toma de decisiones y el uso que se le da a los recursos derivan en repetidas ocasiones de prácticas oportunistas que demeritan el valor que se le otorga a la evaluación, además de disminuir el trabajo en equipo. Se presenta un modelo para medir la percepción de la calidad del servicio por parte de los estudiantes del Instituto Tecnológico de Celaya, como parte del sistema de control de calidad, basado en el soporte teórico de varios autores que han desarrollado este tema (SERVQUAL y SERPERF). Se genera un instrumento adaptado al ámbito estudiantil de la institución llamado SERQUALITC. El artículo presenta las áreas o departamentos a evaluar, así como la dimensión conveniente, además del número de ítems utilizados por la escala de Likert, y se menciona el estudio de validación del instrumento. Finalmente se presenta el modelo que plantea una visión global del proceso de evaliación de calidad incluyendo servicios de acciones de corrección que permitan la mejora continua.

Palabras clave: Evaluación de Instituciones de educación Superior. Calidad en el servicio, Instituto Tecnológico de Celaya, gestión universitaria.

\section{INTRODUCTION}

The concept of organization is also considered synonymous with business, so that it can be said about a variety of types of organizations including educational institutions. Although each one of these differ from the purposes for which they exist, the members who compose and interests they serve. There are also points of convergence. Higher education institutions (HEI) as well as other organizations are guided by human action, have a culture of their own and are geared to meet the objectives.

Given the new scenarios of competition among educational institutions there is a need to incorporate evaluation as a linked element to the loss of confidence of the State with regard to the social function of the HEIs putting at the center of the debate the quality of education they offer. That is when assessment policies arise while funding is enshrined in this process.

Understand how the HEIs function, requires an organizational analysis, also explains how implementing strategies to maintain educational quality. The agency theory can reflect on the governance of higher education institutions and how it operates in the management and performance that is given to the institution. Governance means the relationship between several participants 
to manage and evaluate the performance of institutions. Moreover, the theory based on the resources and capabilities is linked to agency theory and both help to understand how senior managers or directors exercise decision-making, in this particular case, the use of resources to maintain and position the HEIs as successful organizations in the field of education.

\section{BACKGROUND OF THE PROBLEM}

According to Fernandez (2005) from the national crisis in economic matters there is a restriction of public funding for the social sectors, including the universities. The demand generated a strong diversification of university and non-university HEIs. During the 1990s it was generated in most of the Latin American concerns over the issue of university quality, so they were creating agencies for evaluation and accreditation.

In the agency theory alluded to corporate governance. In this case, it speaks of university governance, which according to Casanova and Rodriguez (1999) provides descriptive and analytical ability to integrate the variety of processes that are articulated in the management exercise of the university ( $p$. 15). In other words, it covers the relationships between the different actors and agents that influence the decisions that they drive to the institutions.

The agents that make university governance in the HEIs are operating strategies to have quality in each of their activities, and at the same time continue to get funding. The success that have agents in implementing strategies will be determined by the ability of these possess when designing the organizational structure, evaluate the performance of staff, and the consolidation of the culture of the organization. Sander (1989) systematized four criteria that reflect the historical development of educational administration, and explicitly illustrate the great influence of the currents arising from business management in practice and analysis of education:

A. Profitability, nourished by so-called scientific management.

B. Performance based on the current human relationships.

C. Adaptability, founded in the current organizational development

D. Relevance, which is related to the social sciences and cultural

The changes generated in the HEIs, such as educational expansion, diversification of institutions and overcrowding, highlight the introduction of the issues of evaluation and quality improvement. Alongside, this requires managers to recognize the institution strategic management as a measure which will facilitate 
managing the use of the physical and human resources to achieve its objectives. The fact of the multiplication of interventions in the forms of financing, accreditation, certification and evaluation is accompanied by the creation of new specialized fields of planning and development associated to the mission, vision, transparency and accountability. The assessment in higher education is directly linked to the achievement of results, so that their performance is associated with federal and state rules prohibiting, encouraging or rewarding certain behaviors and organizational measures.

According to Vargas, Guerra and Bojorquez (2014) for the implementation of the strategy, managers should consider the organizational structure, which determines how the objectives are set and how resources are allocated. Grouping tasks and functions as well as assigning authority and responsibility are elements that constitute the organizational structure. Another consideration that must be made is how they monitor and evaluate assigned activities. In that sense we speak of a strategic control system that lets know if the objectives are met.

From another angle, organizational culture is defined as the set of values, beliefs and shared by people and groups that make up a company that controls the way in which these interact with each other and with customer's attitudes (Vargas, et al. p. 173). In strategic planning the key elements that contribute to the generation of that culture are the mission, vision and values. In the case of higher education institutions competing with one industry, education, the emphasis is on the quality and efficiency that give each of their services: teaching, research, extension and binding and be constantly innovating and have a positive attitude to the candidates and the academic community, achieving a competitive advantage.

At first, evaluation focused students, after the program, up to the institutional assessment, that according to Martínez (2010) aims to provide rigorous, valid, reliable and evaluative information about an institution or educational program to enable those responsible to take appropriate decisions regarding their maintenance, removal or improvement, increase awareness of the main problems, mobilize collective awareness about important issues, identify areas of inefficiency and assess the impact of certain decisions or policies.

In a brief tour of how emerge assessment policies in higher education, Villaseñor (2003) tells us that three points are identified. The first one (19901996) is associated with the implementation of policy evaluation stage that was linked to academic quality in terms of predefined results and performance of the institutions. The role played by the State is as evaluator and remote monitoring.

A second point is associated to strengthen policy evaluation (1996-2000), where there is a more accurate notion and concept of academic quality. There is a tendency to quality assurance, although still in quantitative terms, as they 
begin to request proof of quality also happens to be the state auditor evaluator. According to Villaseñor (2003) the social role of evaluation-accreditation at the end of the decade was reinforced to be a more effective tool to transform higher education institutions in organizations serving the knowledge economy (p. 28). All these changes have generated greater competitiveness among stakeholders, as individuals seek to maximize their personal benefit.

The third moment of the assessment is linked to policies of quality assurance (2000-2002). The starting point is the planning directed to operating rules and supervision of the Ministry of Public Education (Secretaría de Educación Pública, SEP), policies focus mainly on Institutional Strengthening Integral Program (PIFI) in that becomes a measure for obtaining funding through the revision of consolidation of academic bodies, updating the plans and curricula, retention, graduating and the tracking rates of graduates among others.

That said Ibarra (2009) notes that the evaluation system increases the drivability and government control over institutions, academics and students. The shared discourse focuses on quality management as a means to obtain financing, while actors are more concerned with meeting certain indicators that lead to institutional simulation practices, neglecting what is truly valuable for the useful. In an effort to be the best and position in the top rankings, higher education institutions must deal with opportunistic practices that may arise as a result of the conflicts associated with information asymmetries in obtaining financing.

Much has been written about the importance of measuring levels of customer satisfaction in organizations also can identify the strengths and weaknesses of the service, to explore in the image and perceptions of users. In recent years, educational institutions have joined this type of analysis because the transcendental results to continuous improvement and implementation of quality systems.

In many institutions of higher education around the world has been significant research to measure the services offered by the students. Some are mentioned below. In Venezuela it was developed and applied an instrument called SEUE (Satisfaction of University Studies with Education). The instrument consists of 93 items, divided in 10 sections: Services, basic needs, security, economic security, emotional security, belonging to the institution or student group, working system, progress of personal success, recognition of success and personal fulfillment (Gento Palacios y Vivas Garcia, 2003).

University of Tamaulipas was conducted in a similar study, which concluded that the variables that influence student satisfaction are Attitude of the teacher, teacher planning of the subject and review of examinations. Also the importance of the Classrooms conditions and finally adequacy and information 
services that are given by the same university provides (Salinas et al., 2008) is mentioned.

Peña (1997) in his paper discusses the application of concepts of quality control and total quality to improve the quality of teaching at the university. In this work, three basic teacher controls are presented. For Jimenez Gonzalez (2011), student satisfaction is a key element in assessing the quality of education, reflecting the efficiency of academic and administrative services: Satisfaction with the learning units, with interactions with their teacher and classmates, as well as facilities and equipment.

Duque and Chaparro (2012) presents a very interesting research on measuring the perception of quality in the Universidad Pedagógica y Tecnológica de Colombia (UPTC) seccional Duitama, with an initial instrument of 45 items, but after doing studies of validity and reliability, the instrument is reduced to 22 items. The instrument was applied to students in the last three semesters of careers offered by the Pedagogical and Technological University of Colombia (UPTC) Sectional Duitama, presenting a comprehensive analysis including the procedure used in building and refining the multi scale - items to measure the construct. Duque and Chaparro conclude that to provide quality education is necessary to discover the components of the quality of education for the consumer (student) that are relevant and at such competition can make a difference and gain consumer loyalty.

Mejías and Alexander (2004) presents a model for measuring service quality in university graduate engineering studies of the University of Carabobo as the basis for the implementation of a quality management system, using the SERVQUAL instrument as theoretical support emphasizing validation of the instrument with very high validity and reliability indicators that allow suggest the questionnaire so that it can be applied to other university study programs. This model consists of 8 steps: Step 0, achieve management commitment. Step 1, identify processes carried out in the organization as well as their interactions. Step 2, determine the optimal sample size. Step 3 SERQUALing apply the questionnaire to the selected sample. Step 4, verify the reliability and validity of the instrument. Step 5, identify the underlying dimensions. Step 6, evaluate the quality of service provided by the organization. Step 7 , standardize the process of measuring the quality of service provided and step 8 , improve the quality of service provided.

The study concludes that this instrument allows determination of the most relevant attributes for students, which would help identify great opportunities for improvement in service delivery programs of graduate study and provide criteria for prioritizing action improvements plans to the decision- 
making process. It is achieved an analysis of factors and dimensions in 5 among them which are defined tangibles, schedules and appearance of staff.

\section{DELIMITATION OF THE PROBLEM}

The study of the IES within a framework of strategic management allows analyzing specifically how they apply their strategies in the daily task of maintaining its educational quality. Seen from the agency theory and the theory of resources and capacities, HEIs face challenges involving the management of uncertainty, opportunistic practices and good use of resources. The aim of this paper is to present an overview of how the evaluation process, the actors involved and conflicts that may arise as a result of that process.

In the Technological Institute of Celaya, until August 2015 are registered 4058 undergraduate students and 252 graduate students. Therefore, they are considered for this project only undergrads. They are included in all specialties; the measuring instrument will be apply in November and will take place online using it is Integrated Information System. It will be made voluntarily, sending the invitation through institutional and personal mailings of students, with the possibility that students choose areas evaluated.

\section{DIAGNOSIS}

Integrated policy of the Institute reads The Technology Institute of Celaya as training institution of professionals for more than 56 years of service, is responsible for creating, maintaining, and improving both training and infrastructure conditions for the integral development of students as well as workspaces of staff working and the general public visiting its facilities, as a commitment to universal human rights, responsibility for improving educational quality and environmental care.

To help achieve this policy the quality management system was implemented since 2004, suffering 12 amendments to date. There are 5 strategic processes, Academic, Planning, Bonding and Linking, Resource Management and Quality. The Academic process is continuously evaluated every semester by an instrument that Mexico National Technology (formerly DGEST) designs, however, the assessment of the other processes are the responsibility of each school. 


\section{THEORETICAL FRAMEWORK}

The use of the resources and capabilities are distinctive features in each one of the organizations. According to Peng (2012) resources are defined as real or tangible assets (those who can see and quantify) and intangible (those that are hard to see and quantify). These resources are used by a firm to choose and implement their strategies. Wernerfelt (1984) suggests that the most important tools to dominate the market are strongly related to the resources of the company in terms of strengths and weaknesses. A useful tool in the strategic planning of organizations is the SWOT matrix, where internal factors (strengths and weaknesses) and external (opportunities and threats) by way of diagnostic analyzes and allow institutions compared to others in the same industry for see in what ways they can improve.

The evaluation of the IES has become a controversial topic while its impact on the substantial activities of universities has been affected. House (2000) defines evaluation as an informed judgment, value judgment or recommendation which in turn qualifies and / or categorizes is comparative in nature and is based from standards, criteria, abstract principles and particular cases. Being a complex issue, assessments do not always happen the same way and not turn out to be of good quality, because sometimes the evaluators are just trying to meet the sponsor (the state, the institution, etc.).

Opportunistic practices in assessment processes affect the quality of institutions. Opportunistic means that the actor is guided by his or her own interests and acts under the logic of instrumental rationality, affecting their objectivity in the evaluation. In addition, one of the main characteristics of organizations is that they are guided by the efforts of managers and administrators, and its intention is to avoid such practices at all costs. These should maintain ties of cooperation, be well organized and have confidence in the partners involved as to conduct assessment involving multiple actors are required.

According to Varela (2008) evaluation should be a system designed to improve and streamline the operation of the higher education system, reducing or avoiding bureaucratic bodies. But, unfortunately scholars have played a role as directors or managers to devote to filling out forms, also that belonging to the National System of Researchers (SNI) generates competition and pressure between them, creating environments of tense no collaborative work.

The evaluation is a potentially political or politicized activity and not easy to assure a consensus, basically generating various evaluation programs National Research System (SNI), National Commission on Higher Assessment (CONAEVA) Evaluation Committee Higher Education (CIEES), National Center

400 - RBPAE - v. 32, n. 2, p. 393 - 420 mai./ago. 2016 
for Higher Education Assessment (CENEVAL) Professional Improvement Program (PROMEP). These and other evaluation programs are extensions of control that today have to limit the "autonomy" of the various stakeholders, hence the need to balance the evaluation forms. It is needed this qualitative part that allows the processing, exploiting the quantitative results in permanent change goals.

\section{SUCCESSES AND PERVERSE EFFECTS OF EVALUATION IN THE HEIS}

Developments that have taken evaluative processes in the HEIs have happened at different times and for similar purposes as noted. The successes of the evaluation according to Ibarra (2009) are: enabled the mobilization of the institutions breaking inertia and promoting change, allowed a more participatory and realistic planning, facilitated greater coordination between the various evaluation programs, allowed the extraordinary access to financial resources to develop academic projects that otherwise would not materialized; and it sets clear and measurable indicators.

From the point of view of the theory of resources, Toro (2006) mentions that the resources that companies have, their unique capabilities and core competencies should help them create their differentiation strategies programs, actions and projects and the products or services they give to society. HEIs have a great responsibility in the training of professionals to provide practical knowledge to society. As a result, their efforts to maintain educational quality are doubled while the evaluation process serves as a regulator.

Although evaluation comes with plausible ideal of improving the quality of the HEIs, the perverse effects that arise as a result of it will not wait, as in the case of some consequences identified in the census tests, evidence of deceptive marketing schools, mostly of private support seeking to attract students. The impoverishment of the curriculum stems from the tendency of many teachers to teach for testing neglecting fundamental aspects that will not be evaluated and rejection of students against education focused on preparing for the test, among others.

\section{CONTEXTUAL FRAMEWORK}

One of the key issues of agency theory is the problem that arises in the relations between principals and agents, i.e. senior officers and boards of 
directors. The following table 1 illustrates broadly the forms of governance in the Mexican HEIs.

Table 1. Forms of governance in the Mexican HEIs.

\begin{tabular}{|c|c|c|c|c|c|}
\hline Government & $\begin{array}{c}\text { Elite } \\
\text { democracy }\end{array}$ & $\begin{array}{l}\text { Hierarchy- } \\
\text { bureaucracy }\end{array}$ & $\begin{array}{c}\text { Oligarchy } \\
\text { entrepreneurial } \\
\text { or religious }\end{array}$ & $\begin{array}{l}\text { Academic } \\
\text { Oligarchy }\end{array}$ & $\begin{array}{l}\text { Bureaucratic } \\
\text { oligarchy }\end{array}$ \\
\hline $\begin{array}{c}\text { INSTITUTIONAL } \\
\text { AUTHORITY }\end{array}$ & $\begin{array}{l}\text { Shared between } \\
\text { different bodies }\end{array}$ & $\begin{array}{l}\text { Falls on a } \\
\text { person who } \\
\text { derives his } \\
\text { power from } \\
\text { a delegation } \\
\text { of the federal } \\
\text { executive }\end{array}$ & $\begin{array}{l}\text { Rests with a } \\
\text { small group of } \\
\text { people, most of } \\
\text { them outside the } \\
\text { institution but } \\
\text { with economic } \\
\text { and academic } \\
\text { interests in it }\end{array}$ & $\begin{array}{l}\text { Rests with a } \\
\text { small group } \\
\text { but whose } \\
\text { key feature is } \\
\text { that these are } \\
\text { people with } \\
\text { high academic } \\
\text { standards and } \\
\text { recognition }\end{array}$ & $\begin{array}{l}\text { Rests with a } \\
\text { small group } \\
\text { of people } \\
\text { representing } \\
\text { the federal } \\
\text { government, } \\
\text { the state } \\
\text { government and } \\
\text { the employers of } \\
\text { a certain locality } \\
\text { or region }\end{array}$ \\
\hline $\begin{array}{l}\text { DECISION } \\
\text { MAKING }\end{array}$ & $\begin{array}{c}\text { Focused on } \\
\text { institutional } \\
\text { development }\end{array}$ & $\begin{array}{l}\text { Focused on } \\
\text { the different } \\
\text { modalities } \\
\text { (industrial, } \\
\text { agricultural, } \\
\text { forestry) }\end{array}$ & $\begin{array}{l}\text { Based on } \\
\text { market criteria }\end{array}$ & $\begin{array}{l}\text { Guided by the } \\
\text { development of } \\
\text { knowledge in } \\
\text { certain areas }\end{array}$ & $\begin{array}{c}\text { According to } \\
\text { the needs of } \\
\text { a professional } \\
\text { market }\end{array}$ \\
\hline $\begin{array}{l}\text { COLLEGIAL } \\
\text { BODIES } \\
\text { INTERNAL }\end{array}$ & Decisive & advisory & advisory & $\begin{array}{c}\text { advisory } \\
\text { Autonomy of } \\
\text { internal advice } \\
\text { (academic) }\end{array}$ & Decisive \\
\hline $\begin{array}{c}\text { EXAMPLES OF } \\
\text { INSTITUTIONS } \\
\text { WITH THIS } \\
\text { FORM OF } \\
\text { GOVERNMENT }\end{array}$ & $\begin{array}{l}\text { Autonomous } \\
\text { public } \\
\text { universities }\end{array}$ & $\begin{array}{l}\text { The National } \\
\text { Polytechnic } \\
\text { Institute } \\
\text { Technological } \\
\text { Institutes }\end{array}$ & Private & $\begin{array}{c}\text { Centers SEP } \\
\text { CONACyT }\end{array}$ & $\begin{array}{l}\text { Technological } \\
\text { universities } \\
\text { Higher } \\
\text { Technological } \\
\text { Institutes }\end{array}$ \\
\hline FINANCING & $\begin{array}{c}\text { Federal } \\
\text { and State } \\
\text { governments }\end{array}$ & $\begin{array}{c}\text { Depend } \\
\text { academic, } \\
\text { financial and } \\
\text { organizational of } \\
\text { a central entity }\end{array}$ & Own resources & $\begin{array}{c}\text { Federal } \\
\text { government }\end{array}$ & $\begin{array}{c}\text { Federals } \\
\text { government, } \\
\text { state } \\
\text { government and } \\
\text { private sector. }\end{array}$ \\
\hline $\begin{array}{c}\text { LEGAL } \\
\text { PERSONALITY }\end{array}$ & $\begin{array}{l}\text { Decentralized } \\
\text { bodies }\end{array}$ & $\begin{array}{l}\text { decentralized } \\
\text { agencies }\end{array}$ & $\begin{array}{c}\text { Civil } \\
\text { associations }\end{array}$ & $\begin{array}{l}\text { Associations } \\
\text { and civil society, } \\
\text { decentralized } \\
\text { organizations }\end{array}$ & $\begin{array}{l}\text { Decentralized } \\
\text { state agencies }\end{array}$ \\
\hline \multicolumn{6}{|c|}{$\begin{array}{l}\text { GOVERNMENT BODIES } \\
\text { It specifies who (person or group of people) have legitimate authority to make decisions and in which areas. } \\
\text { The university councils (political, academic) } \\
\text { The boards of government (prime role: to appoint the rector) } \\
\text { The governing (faculties: administrative, representative, executive and "initiative") }\end{array}$} \\
\hline
\end{tabular}

Source: Own elaboration based on López Zárate, R. (2003).

The Technological Institute of Celaya has a Quality Management System. In it is set the commitment to implement all processes in the customer satisfaction and continuous improvement according to ISO 9001: 2008 / NMX-CC-9001- 
IMNC-2008. These commitments are established through a document called "Student Agreement" (ITC-AC-PO-001-01) on it is specified the following:

A. Vocational (compliance plans and curricula).

B. Teaching practice (student-teacher relationship in the classroom)

C. Attention at counter (School services, financial resources, etc.)

D. Student Services (student coordinator career- relationship)

E. Support services (visits to companies, information centers and computing services, cafes, transport)

Quality in the service of an educational institution is reflected in compliance and user satisfaction about the different services offered. This project seeks to create a methodology for measuring satisfaction to provide reliable information and help making decisions of administrative leaders towards continuous improvement of the processes that the institution offers. It begins with a thorough analysis of the state of art for the search of a model evaluating customer satisfaction according to the needs of the institution, followed by the identification of areas that provide direct services to students on campus and their integration into student engagement, design evaluation instruments with their analysis of validity and reliability, use the correct type of sample and sample size it is critical for proper statistical analysis, which is why these aspects are justified in the investigation.

Collect and process information through the most convenient techniques using computer tools and statistics will be essential for the development of research and finally the proposal seeks to make reports on the results obtained either from generally evaluated area as in general form.

It is intended that the main impact of this model is its use in all National Institutes of Technology of Mexico.

\section{INTERVENTION PLAN}

\section{A. Strategic objective}

1). General

Build and implement a model that allows the measurement of perception of customer satisfaction in the services offered by the Technological Institute of Celaya directly to students. 
2). Specific

a) Determine the dimensions or aspects to be evaluated.

b) Identify the factors that affect each of the selected dimensions.

c) Design measurement instruments.

d) Conduct studies of validity and reliability of measuring instruments.

e) Design formats to capture and analysis of information.

f) Establish indicators of satisfaction and institutional goals.

g) Apply the model for the analysis of the perception of students about the services offered by the institution.

h) Implement improvement actions derived from the analysis of the results together with the areas evaluated.

i) Validate the model using a second application and analysis of the results obtained.

The level of intervention is organizational because it involves changes in all the Technological Institute of Celaya, including Campus 2.

\section{STRATEGIES}

The following table 2 summarizes the proposed activities for intervention

Table 2. Activities of organizational intervention.

\begin{tabular}{|c|c|c|c|}
\hline No. & Activity & $\begin{array}{c}\text { Period of } \\
\text { embodiment } \\
\text { Indicate month }\end{array}$ & $\begin{array}{l}\text { Deliverable results of the } \\
\text { activity }\end{array}$ \\
\hline 1. & $\begin{array}{l}\text { Review of the state of art based on studies of } \\
\text { customer satisfaction for the adaptive model to the } \\
\text { institution. }\end{array}$ & September & $\begin{array}{l}\text { Report reviewing the state } \\
\text { of the art. }\end{array}$ \\
\hline 2. & $\begin{array}{l}\text { Selection of dimensions and aspects to be } \\
\text { evaluated based on the state of the art analysis } \\
\text { and observations made to the Quality Management } \\
\text { System of the Technological Institute of Celaya. }\end{array}$ & October & $\begin{array}{l}\text { Matrix of dimensions } \\
\text { identification and service } \\
\text { aspects. }\end{array}$ \\
\hline 3. & $\begin{array}{l}\text { Identification of factors that add value to established } \\
\text { dimensions. }\end{array}$ & October & $\begin{array}{l}\text { October Matrix incidents by } \\
\text { attributed dimension factors. }\end{array}$ \\
\hline 4. & $\begin{array}{l}\text { Design of measuring instruments to each of the } \\
\text { departments or areas to be evaluated. }\end{array}$ & October & Measuring instruments. \\
\hline 5. & $\begin{array}{l}\text { Validation and reliability of measuring instruments } \\
\text { (type selection and sample size, pilot, etc.). }\end{array}$ & October & $\begin{array}{l}\text { Report validity and reliability } \\
\text { of measuring instruments. }\end{array}$ \\
\hline 6. & Application of instrument & November & Report of results. \\
\hline 7. & Design model & November & Model \\
\hline
\end{tabular}

Source: Own elaboration. 


\section{SCALES MEASURING QUALITY OF SERVICE}

In conducting the literature review on the subject of quality service it is identified that there are two more instruments mainly used, the Servqual and Servperf. The Servqual scale is used to measure customer perceptions regarding service quality (Parasuraman, Zeithaml y Berry 1988). It includes 22 phrases that measure customer expectations and 22 similar phrases that measure customer perceptions and quality of service is established by differences of the scores assigned to the customer expectations and perceptions. This scale has been criticized by several authors, is especial with correspondence between theory and statistical management that has been given to support the dimensions that make up the quality of service and typecasting regarding the methodology and operationalization (Cronin 1994).

The Servperf scale uses only the 22 items of the original scale of Servqual related to perceptions (Cronin, 1994) considering that this is sufficient to determine the quality assessment of any service and is less confusing measure the quality of service based only in performance. In the case of evaluation of perceived quality in higher education institutions, this scale is most often used, although some of them use Servqual but considering only the items related to the perception of quality.

\section{METHOD}

The methodology focused on the consultation of secondary sources, reviewing literature on the subject of service quality, compiling that of greater importance. Thus, it was decided to use the Servperf scale in that it is the most suited to the perception of the quality educational issues, and from it is built the instrument adapted to the educational reality of the institution and considering also that the scale Servperf reduces the amplitude of the questionnaire making it easier and less mental fatigue for young people. On the other hand, since the research is quantitative in nature, once it is built the instrument is applied to a pilot sample of 83 students to conduct studies of validity and reliability with appropriate statistical techniques using SPSS version 22 package. 


\section{TECHNIQUES AND TOOLS}

The study required the following documents for the development

1) The philosophy of the institution

2) Quality Manual developed by Management System

3) The document Contract with the student.

The investigation applied is documentary exploratory on the review of the state of art based on studies measuring the perception of quality educational services for the design and construction of measurement model including an instrument with dimensions, items and scales that fit the institution.

After analysis of several researchers on the topic of measuring customer satisfaction in any organization, but especially in educational institutions of higher level, it is decided to use the SERVQUAL and SERPERF model and their adaptation to the educational field of ITC and considering only the perceptions quality of service, it was decided to call it SERVQUALITC. The original instrument included 20 items that should be evaluated by a Likert scale of 1 to 5 where 1 is strongly disagree and 5 fully agree.

The instrument was presented to a group of fellow teachers and students of the Institute for analysis of relevance and adaptability to the educational environment. Regarding content validity, the consultation made to the state of this art gives it validity and the items are suitable for making measurements.

A validation study and reliability of the measuring instrument to give confidence to the study using Cronbach it is necessary, to do a pilot test and statistical techniques that apply appropriate using the statistical package SPSS version 22, the AMOS V20.

\section{RESOURCES}

Since the survey will be applied online, it must use a software tool, including those offered for free can be on the network as Gmail, SurveyMonkey, Wikispaces, etc. Either use the platform MOODLE virtual institution called Lynx. It will be necessary computer equipment (computers, printers, storage equipment, internet, etc.), involve human resources as support for information capture, counting with students in social service of the same institute

Under the analysis of the document "Student Contract", the areas to be evaluated are presented in Table 3, the departments listed 1 to 7 , are evaluated with SERVQUALITC instrument and for the other four were used other instruments.

406 - RBPAE - v. 32, n. 2, p. 393 - 420 mai./ago. 2016 
Table 3. Departments or areas to measure the perception of quality.

Source: Own elaboration

\begin{tabular}{|l|}
\hline Department / Area \\
\hline 1. Computer Center \\
2. Information Center \\
3. Coordinators \\
4. School Services \\
5. Extracurricular Services \\
6. Financial services \\
7. Medical Services \\
\hline 1. Cafeterias \\
2. Cleaning Service \\
3. Shuttle Service \\
4. Monitoring Service \\
\hline
\end{tabular}

The dimensions used and their descriptions are:

1) Reliability. Ability to perform the promised service dependably and accurately on.

2) Answer's capacity. Readiness and willingness of staff to help students and provide the service.

3) Security. Knowledge and care shown by the staff and their ability to inspire trust and confidence.

4) Empathy. Personalized attention offered to students.

5) Tangibles. Appearance of communication materials physical facilities, equipment, personnel and communication materials.

The study of validity and reliability was performed with favorable conclusions, with a Cronbach's alpha greater than 0.7 (Cano 2015). With the confidence of the applied instrument, it was made the quantitative study of descriptive statistics for the analysis of the dimensions and variables used, presenting the results to the educational authorities of the institution for the analysis and approval of the model. Data were tabulated, generating a matrix of 83 by 20 . SPSS version 22 software was used whereby reliability calculations and construct validity is performed. The last two items were in control.

First it was applied the contrast of Bartlett sphericity and measurement of sampling adequacy of Káise, Meyer and Oklin, in order to verify whether it meets the conditions for a factorial analysis. The results were: 
Table 4. KMO and Bartlett test.

\begin{tabular}{|c|l|}
\hline Measure of sampling adequacy Kaiser-Meyer-Olkin. & .936 \\
Bartlett's test of sphericity Chi-square approximated & 2221.161 \\
gl & 105 \\
Sig. & .000 \\
\hline
\end{tabular}

Source: Own elaboration

As the KMO measure is greater than 0.5 is considered acceptable, as well as Bartlett's test, as the level of significance is 0.000 as manifested by Uriel and Aldas (2005) and Pérez (2004). Then it was performed the principal components analysis and Varimax orthogonal rotation method was also performed, grouping in 5 dimensions that generate a cumulative variance of $85934 \%$.

Table 5. Rotated matrix components.

\begin{tabular}{|c|c|c|c|c|c|}
\hline \multirow[t]{2}{*}{ The rotation converged in 9 iterations. } & \multicolumn{5}{|c|}{ Component } \\
\hline & 1 & 2 & 3 & 4 & 5 \\
\hline $\begin{array}{l}\text { If I had problems, questions or concerns, it was shown a sincere } \\
\text { interest in solving it }\end{array}$ & .894 & .251 & .150 & -.003 & .149 \\
\hline The results of my procedure or service were as expected & .857 & .265 & .252 & .035 & .040 \\
\hline $\begin{array}{l}\text { When calling for service / unit I know that I will find the best } \\
\text { solutions. }\end{array}$ & .832 & .216 & .261 & .004 & .309 \\
\hline $\begin{array}{l}\text { The staff is willing to serve my doubts showing confidence, safety } \\
\text { and courtesy. }\end{array}$ & .798 & .219 & -.089 & .275 & .256 \\
\hline $\begin{array}{l}\text { If I needed to solve any problems, questions or concerns, I was } \\
\text { treated in a satisfactory time }\end{array}$ & .788 & -.042 & .404 & .204 & .058 \\
\hline The service is perfectly suited to my needs as a user & .754 & .253 & .260 & .201 & .240 \\
\hline $\begin{array}{l}\text { When I go to the service, I have no problem to contact the person } \\
\text { who can answer my demands. }\end{array}$ & .701 & .217 & .275 & .310 & .271 \\
\hline $\begin{array}{l}\text { The staff that served me showed enough knowledge to answer my } \\
\text { questions. }\end{array}$ & .670 & .462 & .193 & .121 & .254 \\
\hline Equal service was shown for all users. & .623 & .296 & .090 & .185 & .576 \\
\hline $\begin{array}{l}\text { I have found that staff has appropriate programs and computer } \\
\text { equipment to carry out their work. }\end{array}$ & .271 & .869 & .239 & .161 & .117 \\
\hline $\begin{array}{l}\text { I have had the opportunity to check that staff has sufficient material } \\
\text { resources (computers, multifunctional, internet, furniture). }\end{array}$ & .243 & .832 & .093 & .310 & .117 \\
\hline The service hours are convenient. & .460 & .228 & .747 & .056 & .212 \\
\hline There is enough signage to tell me where to get the service I require. & .122 & .311 & .649 & .570 & .123 \\
\hline $\begin{array}{l}\text { The facilities are visually appealing, maintained and suitable to } \\
\text { provide the service. }\end{array}$ & .199 & .498 & .126 & .766 & .083 \\
\hline The number of people who care enough to service users. & .430 & .140 & .488 & .083 & .670 \\
\hline
\end{tabular}

Extraction Method: Principal component analysis

Rotation Method: Varimax with Kaiser Normalization 
Here it can be seen that there is no need to remove any item, therefore, they are considered the 18 initially proposed and the factors were as follows.

Table 6. Classification of factors

\begin{tabular}{|c|c|}
\hline Factor 1 & Items: $2,1,3,4,5,9,8,7 \mathrm{y} 6$ \\
\hline Factor 2 & Items: 11 y 12 \\
\hline Factor 3 & Items: 10 y 14 \\
\hline Factor 4 & Item: 13 y 16 \\
\hline Factor 5 & Item: 15,17 y 18 \\
\hline
\end{tabular}

Source: Own elaboration

The proposed model does not fit this classification of factors, thus, it is required calculating the reliability of each dimension using the indicator Cronbach's alpha.

Table 7. Calculating the reliability of each dimension using the indicator Cronbach's alpha

\begin{tabular}{|l|l|l|l|}
\hline Dimension & Items & Cronbach's alpha & Number of elements \\
\hline Reliability & 1,2, y 3 & 0.951 & 3 \\
\hline Answer's capacity & 4,5 y 6 & 0.780 & 2 \\
\hline Security & $7,8,9$ y 10 & 0.841 & 2 \\
\hline Empathy & 11,12 y 13 & 0.876 & 3 \\
\hline Tangibles & $14,15,16,17$ y 18 & 0.858 & 5 \\
\hline
\end{tabular}

Source: Own calculations.

According to these results it is inferred that the instrument has a satisfactory internal consistency as it is greater than 0.7 (1999, Hair).

The final instrument is set with 20 items, 3 measuring reliability, 3 responsiveness, 4 security, 3 empathy, and tangible dimension 5 and 2 control items. Likert scale was used with options for response options.

1) Strongly Disagree

2) Moderately disagree

3) Neither agrees nor disagrees

4) Moderately agree

5) Strongly agree

The instrument was applied online using the option of questionnaires Gmail and ligating in the virtual page of ITC. It was accompanied by an awareness 
campaign on the importance of participating and responds. The option was given to the student to decide the areas to evaluate, therefore, the number of students was variable for each department or area, being the cafes which had the highest number with 515 and the lowest was financial services with just 283. The results were presented to the educational authorities of the institution for analysis and approval of the model.

\section{RESULTS}

The final model proposed is shown below in figure 1 .

Figure 1. Model to measure the perception of quality of services by students of ITC.

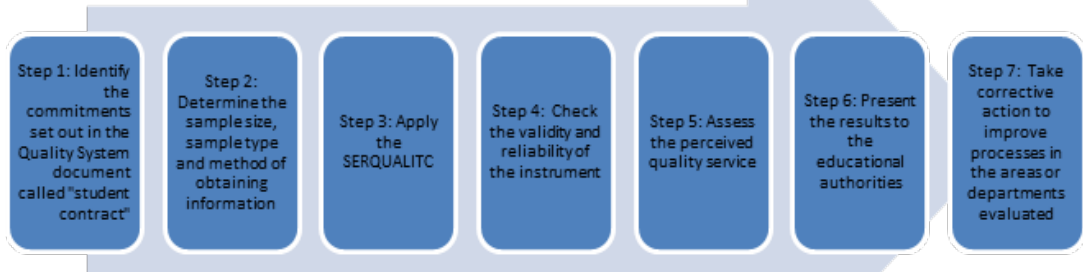

Source: Own elaboration.

To make a comparative analysis it was decided to carry out a statistical study based on the results obtained. In Table 8, a table comparing by area and dimension is presented.

Table 8. Statistical comparative arithmetic means by area and dimension.

\begin{tabular}{|c|c|c|c|c|c|c|}
\hline & Reliability & $\begin{array}{c}\text { Answer's } \\
\text { capacity }\end{array}$ & Security & Empathy & Tangibles & Mean \\
\hline Computer center & 3.58 & 3.60 & 3.80 & 3.50 & 3.54 & 3.73 \\
\hline Information center & 3.89 & 3.84 & 3.95 & 3.78 & 3.84 & 3.75 \\
\hline Coordinators & 3.60 & 3.62 & 3.74 & 3.71 & 3.65 & 3.73 \\
\hline School services & 3.93 & 3.87 & 4.06 & 3.84 & 3.78 & 3.74 \\
\hline Extracurricular services & 3.83 & 3.89 & 3.95 & 3.82 & 3.76 & 3.71 \\
\hline Financial services & 3.88 & 3.90 & 3.98 & 3.90 & 3.84 & 3.66 \\
\hline Medical services & 3.36 & 3.30 & 3.57 & 3.28 & 3.22 & 3.54 \\
\hline Mean & 3.72 & 3.72 & 3.86 & 3.69 & 3.66 & \\
\hline
\end{tabular}

Own elaboration

410 - RBPAE - v. 32, n. 2, p. 393 - 420 mai./ago. 2016 
Related areas with cafes, cleaning and security services were measured with other instruments; the results obtained are presented in Table 9.

Table 9. Statistical comparative arithmetic means of the areas measured with other instruments.

\begin{tabular}{|c|c|c|}
\hline & Arithmetic mean & Scale \\
\hline Cafeterias & 3.27 & 1 very bad to 5 very good \\
\hline Surveillance services & 3.62 & 1 in disagreement to 5 fully agree \\
\hline Cleaning services & 3.78 & 1 very bad to 5 very good \\
\hline Transport services & 3.82 & 1 very bad to 5 very good \\
\hline
\end{tabular}

Source. Own elaboration.

For purposes of making a comparative analysis more suited to the measurement range of skills used in academics, Table 10 represents the score obtained by the perception of students and colors that simulate approval (yellow) or presented fail (red) services.

Table 10 Qualification obtained from areas or departments descending order.

\begin{tabular}{|l|l|}
\hline DEPARTAMENT/AREA & SCORE \\
\hline 1. School services & 78 \\
\hline 2. Financial services & 78 \\
\hline 3. extracurricular services & 77 \\
\hline 4. Information center & 77 \\
\hline 5. Transport services & 76 \\
\hline 6. Cleaning services & 76 \\
\hline 7. Coordinators & 73 \\
\hline 8. Computer Center & 72 \\
\hline 9. Surveillance services & 72 \\
\hline 10. Cafeterias & 65 \\
\hline 11. Medical services & 63 \\
\hline
\end{tabular}

Source: Own elaboration

\section{DISCUSSION AND CONCLUSIONS}

Evaluate and design quality in absolutist terms regardless of the student's perception and measure without him/her persist in this omission would continue in a state of myopia (Duque y Chaparro, 2012). Thrown results indicate that the instrument can be used with confidence. 
However, it is very important to emphasize the commitment of the management. It cannot undertake this model if there is not the commitment of management. The document "contract with the student" is the first step established in the management system quality. However, sometimes it seems to forget that the student is the center of educational work and he/she gets to be treated cold, discourteous and sometimes even rude way. The instrument reveals what is important from the perspective of students and to analyze the strengths and weaknesses of the services the institution offers so that managers come to manage these aspects.

It is important to note that, when presenting the results of this evaluation to the Institute authorities, major changes and corrective actions occurred, especially in the areas which received the lowest scores in this case cafeterias and medical service. The actions taken were welcomed by who headed the evaluation, because they believed on the importance given to it, but especially to students who have benefited from the changes. The process of educational evaluation was not considered in this research, since it is a process established by the National Technology of Mexico and is systemized semiannually. Of course also requires its analysis, but is beyond the scope of this investigation.

Similarly, it is important to emphasize the sample structure of the research, so that statistically is right. That is, the correct calculation of sample size, and suggested a random stratified sampling that includes all careers offered in the Institute of Technology. It is recognized that for this evaluation there was not size or type of sampling was considered to be the first time applied. The survey was open to all who wished to participate. On the other hand, this time only was considered undergraduates; however, it must include graduate students, since they also use the services, perhaps with some modifications to the instrument to make it more suited to graduate needs.

Similarly, emphasis should be given on how to gather the information. Use of technological means is a good choice, but must be accompanied by an awareness campaign to students to answer questionnaires. Maybe make mandatory the instrument for those students they are randomly chosen, as is done in the evaluation of teachers. The descriptive statistical analysis is also very important to perform professionally summarized in tables and graphs showing the actual results of the evaluation and easy to interpret for those who make the decisions of correction. Can also include other statistical analyzes, such as analysis correlation, comparison of averages by gender, career, etc.

For this occasion, five dimensions of evaluation that were used and as suggested by the theoretical sources consulted, but should not rule out the 
possibility of including other dimensions that might be relevant to the evaluation of the perception of service quality. A deeper analysis of art can give the possibility to explore new dimensions.

Some areas were evaluated with instruments other than SERVQUALITC by the nature of the service. These areas are cleaning services, security services; cafeteria service and shuttle service were evaluated. The latter considering the transport takes students from one campus to another $(1.5 \mathrm{~km}$. about $)$ and practice trips, visits, events, etc. These instruments were proposed by theoretical consultations developed related to the subject and the suggestion of the team that participated in this research. However, they do not include analysis of validity and reliability, so it would be worthwhile to perform such analyzes that give confidence to the instruments.

This proposed model may be susceptible to be used by the technological changes that are part of the educational system called National Technology Mexico and home to over 250 federal and decentralized institutions, with adaptation to the particular contextual reality of each one. The educational process cannot be either passive or routine, it is more active and its development requires constant changes on people who are training (students). This change does not occur immediately, but must be managed by all possible means and requires the commitment of all involved in the process.

The higher education environment is changing exponentially. These changes merit that studies are conducted periodically in order to discover new needs, desires and expectations of students and design and implement services that meet them. As expressed by Ospina (2008) "Quality education is one that produces changes in the student through the appropriation of knowledge for transfer to the social realities of their environment.

The organizational changes resulting from the automation of tasks and functions made a shift from a rigid to a flexible manner. Such processes generated managers to focus more on people and situations. The assessment also implies that actors know and engage in activities that entails. According to Eisenhardt (1989) agency theory arises when the owners (principals) begin to delegate the managerial functions and decision making to other individuals (agents). The relationship arising between both agents will determine the direction of organizations.

As pointed out by Fama and Jensen (1983) the main reason why agency problems persist are asymmetries of information between principals and agents. In terms of evaluation, as is pointed out, the tendency to opportunistic practices can be an indication of simulation practices not only affects the organization but also the reputation of the evaluators. The emphasis of this theory according to Daily, Dalton and Cannella (2003) is associated with two factors: firstly, it is 
a very simple theory, in which large companies are reduced to two participants, managers and shareholders, and interests of each are supposed to be clear and consistent. Second, the notion of human beings is that they are willing to sacrifice personal interests for the interests of others.

In the realm of HEIs, basic management functions allow them to maintain an adequate rate of which is directed towards. It is necessary to carry out a planning that determines which results are to be achieved and establish appropriate strategies for their achievement. In a second time, it should organize how the proposed results will be achieved. It will be necessary to identify the division of tasks and functions to each individual or groups within the organization. In the same process, leadership plays a vital role, since the function of those who lead and motivate members of the organization influence how articulate efforts and objectives are achieved. At the same time, there will be strategic control systems to check whether they have achieved the expected results through it may identify performance deviations and take corrective measures to be channeled in achieving the objectives.

In a critical analysis of Ibarra (2003) on the university defines this as an invented reality, the regulations would be the foundation, the coordination system which gives structure, leaving aside the essence of the actors, the teaching as such, and there needs to demonstrate that it meets the challenges. It is forgotten the substantive role of the university to respond to social problems and all is imagined by numbers and indicators.

Undoubtedly, the control exercised by senior managers in the organization has to do with the kind of results that are generated, since managers are who are responsible for joint teamwork and decide who occupy strategic positions. Precisely Zajac and Westphal (1996) note that the power that managers have in relation to the decision to elect board members, considering such factors as reputation, expertise or sympathy that the manager has, leads to strengthening his leadership.

From that stage, it is required more efforts among stakeholders to be shared, which are fighting for the generation of knowledge created by multidisciplinary teams so that teamwork is strengthened and that researchers do not become lonely players. Undoubtedly, the negotiations will also function as a regulator of the rules in the institution. 


\section{CONCLUSION}

A. Evaluation

This study contributes to the quality management system to achieve the ISO 900 recertification giving much pride to school, but most importantly to make the necessary corrective actions to improve services and remain one of the best technological institutes of the country.

A. Cost / benefit

In reality the costs are few, since the institution has the equipment and tools physical and materials for the project necessary, the will to do the project and the time required for this are what you need, the benefit will be very big long as the corrective actions that each area competence for continuous improvement are made.

The major challenges facing higher education institutions with respect to evaluation, accreditation and quality assurance revolve around generating knowledge applicable to local contexts, adopting regulatory policies that can minimize the risks of low educational offerings quality (private sector, mostly), encourage the active participation of academic actors (teachers, students) on the conceptualization of the quality joint assessment processes with improvement concepts, autonomy and academic freedom.

The decisions made within institutions of higher education are framed first by the historicity of them, the organization and each particular structure, as well as the "dependency" of government funding based on the joint knowledge generation. These elements are closely related to the "games" of power that are "cooked", mainly within universities intermittently when making decisions that set the course of the university way.

The agency theory enables to analyze from the university government how the HEIs organize, discuss and develop assessment processes, facing opportunistic practices and complex environments involving actors in few cooperative ties due to power struggles and personal interests. Moreover, the theory of resources and capabilities facilitates understanding the use given to the tangible and intangible resources in making decisions that lead to achieving the objectives.

Moreover, it is necessary that education as a public good and students as subjects of law should be resumed, in that sense. Latapí (2008) reflects on the quality of education, alluding to four traits, character, intelligence, feelings and 
freedom associated with the social function of the university to train professionals with integrity and consistent with what they say and do, acquire general knowledge but also those specialized for specific tasks, training in values (tolerance, justice, equity), the cultivation of the imagination and empathy, as well as allow students to feel free to reach their goals and make sense of the role they play in society, without focusing only on obtaining economic or recognition of merit.

Similarly, the evaluation should be a tool to encourage continuous improvement. Self-evaluation becomes a key part of these processes, but this will be useful to the extent that stakeholders are aware of their actions, that there is a change of mentality less focused on control, money and the market, greater teamwork and knowledge generation applicable to the local context.

Evaluation is not an automatic process, not because it is evaluated is improved. Obtaining greater financial resources does not raise the quality, i.e. assess is a process that involves seriousness, objectivity and the capacity to make decisions according to the results. An important element to consider in the evaluation process is the "interest", i.e., the ends that people raised in the evaluation are vital to include the interests of all concerned groups of program or policy and use the power as a mean to balance and participation of members.

\section{REFERENCES}

Cano, T., Zarate, C., Lugo, E. (2015). Validez y Fiabilidad de un Instrumento para medir la Percepción de la Calidad del Servicio por parte de los Estudiantes del Instituto Tecnológico de Celaya. Academia Journal.com

Casanova Cardiel, H., \& Gómez, R. R. (1999). Universidad contemporánea. Política y gobierno, 2. México: Centro de Estudios sobre la Universidad-UNAM. Cronin, J. y Taylor, S. (1994). SERVPERF vs. SERVQUAL reconciling performance

- based and perceptions- minus expectations measurement of service quality, journal of marketing, vol. 58, January p.p $125-131$.

Daily, C., D. Dalton, and A. Cannella (2003). Corporate governance. AMR, 28: 371-382.

Díaz, D. (2003). Validación de una escala de medida para la determinación de la calidad de servicio en una institución de educación superior. México: Chiclayo. 
Duque, E. y Chaparro, C. (2012) Medición de la percepción de la Calidad del servicio de Educación por parte de los estudiantes de la UPTC Duitama. Revista Criterio Libre, vol. 10 Numero 16, p.p. 159- 192.

Eisenhardt, K. (1989). Agency theory: An assessment and review. Academy of Management Review, 14:57-74.

Fama, E. and M. Jensen. (1983). Separation of ownership and control. Journal of Law and Economics, 26: 301-325.

Fernández Lamarra, N. (2005). La evaluación de la calidad y su acreditación en la educación superior en América Latina y el MERCOSUR. En: J, Mora y N. Fernández. Educación Superior convergencia entre América Latina y Europa, Procesos de evaluación y acreditación de la calidad. Argentina: Universidad Nacional de Tres de Febrero. Pp. 95-114.

Franco Espejel, G. M. (2003). Validación del SERVQUAL, en una institución pública mexicana. Revista Unidad Profesional Interdisciplinaria de Ingeniería y Ciencias Sociales y Administrativas, 33(1), 1-4.

Gento Palacios, S. y Vivas García, M. (2003). El SEUE: un instrumento para conocer la satisfacción de los estudiantes universitarios con su educación. Acción Pedagógica, 12(2), 16-27.

Hair, J.; Anderson, R.; Tatham, R. Black, W. (1999). Análisis Multivariante. Madrid: Prentece Hall.

House, E. R. (2000). Evaluación, ética y poder. España: Morata, pp. 15-62.

Ibarra Colado, E. (2003). Prólogo. En: Porter, Luis. La universidad de papel. Ensayo sobre la educación superior en México. México, UNAM/CIICH. P. p 7-30.

Ibarra Colado, E. (2009). Impacto de la evaluación en la Educación Superior Mexicana: valoración y debates. Revista de la Educación Superior, Vol. XXXVIII, No. 149, enero-marzo 2009. Pp. 173-182. México.

Jiménez González, A., Terriquez Carrillo, B. y Robles Zepeda, F.J. (2011). Evaluación de la satisfacción académica de los estudiantes de la Universidad Autónoma de Nayarit. 
Latapí Sarre, P. (2008). Una buena educación. Reflexiones sobre la calidad. México: Universidad de Colima. Pp.17-32.

López Zárate, R. (2003). Formas de gobierno y gobernabilidad institucional. Análisis comparativo de seis instituciones de educación superior. México: ANUIES. Cap. 3.

Martínez Rizo, F. (2010). Usos y abusos de la evaluación educativa. Este País, No. 232. México.

Mejías, A. y Alexander, A. (2005). Modelo para medir la calidad del servicio en los estudios universitarios de posgrado. Revista Universidad, Ciencia y Tecnología volumen 10, numero 34 p.p 81-85

Oldfield, B. M. y Baron, S. (2000). Student perceptions of sevice quality in a UK university business and management faculty. Quality Assurance in education, 5(1), 85-95.

Ospina, R. (2008). Calidad de la educación desde la convergencia de criterios de modelos de evaluación de la educación superior 1996 - 2006. Tesis doctoral no publicada, Tunja: Universidad pedagógica y tecnológica de Colombia, departamento de Ciencias de la Educación.

Parasuraman, A., Zeithaml,V. y Berry, L. (1988) Servqual: A Multiple - Ítem Scale for Measuring Consumer Perceptions of Servicie Quality, Journal of Retailing, volumen 64, number 1, spring, 1988. p.p. 12-40.

Peng M. (2012). Global Strategy. Cincinnati: Thomson South-Western.

Peña, D. (1997). La mejora de la calidad en la educación: reflexiones y experiencias. Madrid: Getafe.

Pérez, C. (2004). Técnicas de análisis multivariante de Datos. Prentice Hall.

Prugsamatz, S., Heaney, J. G. y Alpert, F. (2007). Measuring and investigating pretrial multi-expectations of service quality within the higher education context. Journal of Marketing for Higher Education, 17(1), 17-47. 
Reyes Sánchez, O. y Reyes Pazos, M. (2009). Calidad del servicio educativo: Caso de la escuela de artes de la UABC. X Congreso Nacional de Investigación Educativa, México, 1-10.

Salinas Gutiérrez, A., Morales Lozano, J.A. y Martínez Camblor, P. (2008). Satisfacción del estudiante y calidad Universitaria: un análisis explicatorio en la Unidad Académica Multidisciplinaria Agronomía y Ciencias de la Universidad Autónoma de Tamaulipas, México. Revista de Enseñanza Universitaria, 31(4), 3955 .

Sander, B. (1989). Gestión y administración de los sistemas educacionales: problemas y tendencias. Perspectivas, Vol. XIX, No. 2. UNESCO, París.

Toro, D. (2006). En enfoque estratégico de la responsabilidad social corporativa: revisión de la literatura académica. Intangible Capital, No. 14, Vol. 2. Pp. 338358. Universidad Politécnica de Catalunya. Departamento de Organización de empresas.

Uriel and Aldas (2005), Análisis Multivariente Aplicado. Madrid: Editorial Thomson.

Valenzuela R. (2010) Hugo, Los Sistemas de Calidad en las Instituciones Educativas. Tendencias Actuales. Revista Digital la Educación, Organización de los Estados Americanos. Santiago de Chile.

Varela Petito, Gonzalo (2008). La educación superior en México. Planeación, evaluación y entorno. Argentina. Ed. Miño y Dávila. Capítulo III, Pp. 75 a 116.

Vargas Hernández, J. G., Guerra García, E., Bojórquez Gutiérrez, A. y Bojórquez Gutiérrez, F. (2014). Gestión estratégica de organizaciones. Argentina: Ediciones Insumisos Latinoamericanos.

Vergara S. Juan Carlos (2010) Análisis de la calidad en el servicio y satisfacción de los estudiantes de Ciencias Económicas de la Universidad de Cartagena mediante un modelo de ecuaciones estructurales. Revista electrónica de investigación educativa. 
Villaseñor García, G. (2003). La evaluación de la educación superior: su función social. Reencuentro, (36) 20-29. Recuperado de http://www.redalyc.org/ articulo.oa? $\mathrm{id}=34003603$

Wernerfelt, B. (1984). A resource-based view of the firm. Strategic Management Journal, 5: 171-180.

Yeo, R. K. (2009). Service quality ideals in a competitive tertiary environment. International Journal of Education Research, 48(1), 62-76.

Zajac, E. and J. Westphal (1996). Director reputation, CEO-board power, and the dynamics of board interlocks. ASQ, 41: 507-529.

JOSÉ GUADALUPE VARGAS-HERNÁNDEZ é PhD em Economia Organizacional. Professor pesquisador na University of Guadalajara, México.

Recebido em abril de 2016

Aprovado em junho de 2016 